\title{
William James on Truth and Invention in Morality
}

\section{Sarin Marchetti}

\section{OpenEdition}

\section{Journals}

Electronic version

URL: http://journals.openedition.org/ejpap/910

DOI: 10.4000/ejpap.910

ISSN: 2036-4091

\section{Publisher}

Associazione Pragma

\section{Electronic reference}

Sarin Marchetti, « William James on Truth and Invention in Morality », European Journal of Pragmatism and American Philosophy [Online], II-2 | 2010, Online since 21 December 2010, connection on 19 April 2019. URL : http://journals.openedition.org/ejpap/910 ; DOI : 10.4000/ejpap.910

This text was automatically generated on 19 April 2019

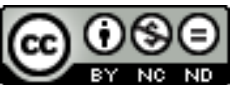

Author retains copyright and grants the European Journal of Pragmatism and American Philosophy right of first publication with the work simultaneously licensed under a Creative Commons Attribution-

NonCommercial-NoDerivatives 4.0 International License. 


\title{
William James on Truth and Invention in Morality
}

\author{
Sarin Marchetti
}

\section{AUTHOR'S NOTE}

I am grateful to Richard J. Bernstein, Akeel Bilgrami, and Russell B. Goodman for their valuable comments on an earlier version of the essay, and to the organizers and participants of the talks at The University of New Mexico, The New York Pragmatist Society, The New School of Social Research and Université de Picardie Jules Verne, where parts of it have been presented.

[T]he moral tragedy of human life comes almost wholly from the fact that the link is ruptured which normally should hold between vision of the truth and action, and that this pungent sense of effective reality will not attach to certain ideas.

The Principles of Psychology vol. II, 547

1 In what follows I shall investigate how the notions of truth and invention inform our moral life. In particular, I will show how this idea has been explored by William James in his seminal essay The Moral Philosopher and the Moral Life (MPML), by far his most clear-cut piece of moral philosophy. I will claim that the dialectics of the essay cannot be apprehended independently from the understanding of the moral psychology and epistemology James elaborates in his writings on pragmatism and the philosophy of mind. In fact, once framed in the relevant perspective, the essay conveys a very different and more radical position that the one usually acknowledged. In MPML James engages in an inquiry into the nature of moral thought and its ability to meet the difficulties of the moral life it should address. The essay criticizes a certain image of moral reflection by questioning its underlying assumptions about the nature of mindedness and the place of truth in the moral life. I shall thus articulate the discussion of James' essay along two directions, one methodological and one substantive. They are, respectively, the anti- 
foundational and anti-theoretical character of moral reflection, and the rethinking of the relationship we have with our interiority that is relevant for ethics as informed by the notion of truth.

2 MPML is at the same time the most quoted and yet the most misunderstood of James' papers - a record it shares with The Will to Believe. My critical target is a received view of James' moral philosophy as a piece of utilitarian moral theory. Such a reading is the result of a superficial analysis of the rhetoric of the essay, together with a reductive and unimaginative understanding of James' theory of truth underlying it. It is my ambition to show that, once viewed in the proper light, the dialectic of the essay will reveal its real stakes: namely, an exercise of conceptual criticism of the very image of moral reflection aimed at showing the dangerousness of conceiving ethics 'in the old-fashioned absolute sense,' that is as 'dogmatically made up in advance' in splendid isolation from the human beings inhabiting it. James is neither interested in advancing any theory of morality whatsoever, nor in individuating the principles of human nature on which such an ethics should be erected. His interest is rather that of showing the shape moral reflection should take to meet the difficulties of the moral life it should address instead of castling itself behind a moral theory or some metaphysical picture of human beings. Moral reflection, according to James, should have an exhortative character, its point being that of gesturing toward the varieties of ways in which we can be - or fail to be - touched by situations that prompt our sensibility and understanding to respond ethically. In MPML James explores the various aspects of our moral life, and shows how a deceptive picture of moral psychology and epistemology hinders us from resolving some of its difficulties. Consequently, if moral reflection aspires to have a genuine grasp of the moral life, it should rethink its very credentials and investigate in the first instance what relationship it should entertain with the varieties of moral experiences articulating our moral life.

3 Placing James' considerations in the wider context of his conception of truth and mindedness will allow us to see the richness of this text as well as to appreciate its antifoundational inspirations. I will be very selective in my use of James, although these themes pervade his whole philosophy and find their most distinctive voice in his masterpiece The Principle of Psychology, which will linger in the background of my investigations. In his writings on pragmatism and the mind James struggles to articulate his insights about the interconnectedness of a refutation of a theoretical - as opposed to a practical - understanding of our mental lives with a refutation of a picture of truth as copying and representation. These two insights are pivotal for the understanding of James' moral philosophy as a whole, and the essay under examination in particular, since in it James complains about the narrow understanding of moral reflection as driven by a distorted intellectualistic characterization of our mindedness and worldliness. My claim will be that, if we frame MPML in this broader context, a much richer image of moral thought - one very instructive for the contemporary debate - will emerge.

\section{米}

James wrote MPML in 1891 as an address to the Yale Philosophical Club. Given the academic setting of the lecture, James' interest was that of showing the limits and point 
of a philosophical account of morality. The aim of the lecture-essay is not in fact the advancement of any moral theory, but the investigation into its very possibility. This point has been surprisingly overlooked in the critical literature on James. A notable exception is the book by Sergio Franzese on James' moral philosophy, in which the author advances a reading of MPML on these lines, that is, as a critical inquiry into the very nature and feasibility of moral reflection. Franzese traces back the deceiving interpretation of the essay to the popular account that Ralph Barton Perry gave of James' moral philosophy in his monumental The Thought and Character of William James, in which James' protégée, by failing to appreciate the leitmotiv of the essay, advanced a very biased reading of his mentor's moral thought. Franzese argues that a more attentive inquiry will reveal how

[t]he essay of 1891 does not work as an outline of a moral theory because it was certainly not intended to be one. On the contrary, it was intended to show the futility of that traditional philosophical task, which is perhaps why philosophers have intended not to read it too closely [...] [t]he 'The Moral Philosopher and the Moral Life' is a critical analysis of the validity of any moral theory, in the terms of its relation to the moral philosopher, rather than presenting another specific moral theory. ${ }^{1}$

5 According to Franzese, MPML has been variously read as a moral system advancing a theory of goods and values, whereas James was interested in showing the futility of such an approach to moral reflection and its prescriptive pretensions. Franzese proceeds in tracing the roots of James' innovative inquiry in the Wundtian school of psychology and its bearings for the debate about the axiological crisis that characterized the end of XIX century and invested the discourse about the statute of philosophical accounts of morality. Alternatively, here I want to explore at some depth the philosophical motives internal to James' thought that prompted such a characterization. Once freed from these misplaced attributions and returned to its proper fieldwork, an opposite picture of moral reflection will be revealed through the lines of the essay. I shall claim that the reading of James' moral thought as a defense of utilitarianism commits a categorical mistake, since not only is James very critical of utilitarianism ${ }^{2}$ - as regards both its underlying moral psychology (an untenable atomistic picture of experiencing and a related narrow conception of consequence), and its teleological aspirations (the sublimation of utility or pleasure as the only criteria of goodness) -, but he is also skeptical about the very possibility of moral theory, be it utilitarian or not. In MPML James is interested in showing if, how, and to what extent our moral life can be pictured and understood by means of moral reflection. For this reason MPML represents a key text for the assessment of James' whole moral philosophy: in it we can find the instructions that will tell us how to read the ethical investigations pervading James' writings. A misreading of MPML will thus convey a paltry understanding of the whole of James's moral philosophy. A good understanding of James' moral philosophy will thus require the proper understanding of the place of MPML in respect to the widespread moral instructions.

James articulates in his other writings. However, it is not easy to characterize the connection between James' methodological considerations on the nature of morality as presented in MPML and the moral ideas as they are explored in his other works. As the vast majority of commentators have suggested, the character of James' investigation was deeply ethical, so that most of his discussions about the mind, the world and the varieties of encounters between the two were driven by ethical concerns. Even metaphysical discussions were for James au fond urged by moral constraints and permeated by moral 
interests. His assertion that the very question between monism and pluralism cannot be settled independently from considerations about the importance of the two options for one's moral life is well known. It is thus difficult to tell the difference between MPML, widely acknowledged as either his only or his clearest work in moral philosophy, and the widespread references to morality pervading his other writings. ${ }^{3}$

7 A fistful of authors ${ }^{4}$ have strived for the understanding of this connection, but the majority of the interpretations failed to appreciate the point due to their misreading of the tone and the aims of the essay altogether, since even if they rightly acknowledge the importance of the essay for the understanding of James' moral philosophy, still they stuck with a reading of it as a defense of a peculiar moral theory. Since I am impatient to present my own reading, in the next section I will briefly sketch the essential structure of the two main families of readings so as to place my own understanding of James' moral philosophy in context.

As I have been arguing, a good reading of MPML represents the necessary conditions to grasp James' conception of ethics, and either this essay has not been recognized as special at all, or its distinctiveness has been misplaced. Ralph Burton Perry's account falls into the first case. Perry, in his monumental work on James, does not appreciate the peculiarity of the essay and melts James' writings together, losing in this way the asymmetry holding between MPML and his other writings containing his moral ideas. In chapters LXV and LXVI of the book he insists on the moralistic and militant character of James' moral reflection. Perry seems to acknowledge the distinctiveness of MPML by saying that the essay is James' only published discussion of theoretical ethics. He claims that in it James addressed the question, raised a couple of years before in his essay titled The Sentiment of Rationality, 'What does the moral enthusiasm care for philosophical ethics?' This question, raised in a paper in which James - among other things investigates the peculiar frame of mind that prompts us to crave for rationality in our philosophical investigations, seems to fit suitably the purposes of MPML. In fact, it conveys the sense of the problematization James addresses in his characterization of the relationship between one's own moral ideas - or 'enthusiasm' - and a reflective - or 'philosophical' - ethics. However, although very encouraging, Perry's account wastes its promises by reducing the reflective discourse about morality to the discussion of the character of individual interests and demands and their relation with the social life in which their bearers partake. Moreover, Perry presents this discourse, which he characterizes as the center of vision of James' conception of ethics, as a fallout of his personal biography. He writes

[t]here is an undeniable moral accent in the life as well as in the thought of William James. In view of the fact that he subordinated thought to action, and therefore in principle accepted the Kantian doctrine of the "primacy of practical reason," it is surprisingly that he wrote so little on moral philosophy. But this comparative inattention to the traditional problems and theories of ethics was offset by the strength of his moral convictions. His total expression was infused with moral zeal - his personal code was rigorous and unmistakable. ${ }^{5}$

The quotation is very perspicacious. Instead of exposing the arguments given in MPML Perry engages in a very captivating survey of James' moral ideas, as they are discussed by James in his other writings. Even if the texts and ideas he presents are of the utmost 
importance and are deeply pertinent for the understanding of the themes tacked in MPML, Perry makes two related mistakes at once: he conflates the reflective with the purely descriptive, and characterizes both as the outcome of James' eclectic personae. Even if the effort to show the deep entanglement of biography and philosophy in James is nothing but praise-worthy, since it is an aspect of his thought that should be remarked with great emphasis, Perry's account went so far as to reduce James' philosophy to his biography, losing in this way the most interesting reflective dimension of his discourse. ${ }^{6}$ It is my claim that if we take James' philosophical insights in their own terms, and try to understand them as the result of reflective investigations, the very connection with the experiences from which such investigations at the same time spring and get transformed will be illuminated. These two aspects - namely, biography and philosophy - must be kept in contrastive tension, since the subordination of one to the other will bring us either to an aprioristic conception of philosophy or to the very opposite annihilation of it, a flattening of one on the other will obscure the nature of their connection. In the case we are examining, that is James' moral philosophy, this tension is built into the very dialectic of MPML. In the essay James pictures the relationship between moral reflection and moral life neither as one of derivation nor of reduction, but rather of mutual definition. Moral reflection emerges from our internal understanding of the practical contingencies of our moral life, but cannot be reduced to them. Moral reflection makes sense on the background of some shared practices and ideas, and the rationality it expresses is internal to such practices and ideas. At the same time, by means of moral reflection we investigate the very conceivability of a certain moral idea or experience, so that its role is not merely descriptive. I will go back to this characterization in the next section. Let me now move to the other family of readings, namely the ones which misplace the distinctive voice of MPML.

Richard Gale's book The Divided Self of William James, whose interpretation of James is remarkable in several ways, represents a good example of a reading mindful of the distinctive place of MPML in James' moral philosophy, but inattentive to its antitheoretical inspiration. Gale tackles the question directly, arguing for a radical distance between James' ethical theory and his normative moral ideas. Let me quote the passage in its entirety, since it is very rich and eloquent. He writes

[J]ames' only published effort to develop an ethical theory is his 1891 essay on "The Moral Philosopher and the Moral Life" [...] [T]hat James never felt the need to publish anything further on ethical theory, either before or after 1891, is strong evidence that he accepted its position throughout, especially as there is nothing in his unpublished writings indicating any doubts or reservations, only further corroborations of the 1891 essay. The word theory is italicized so as to emphasize the contrast with the moralizing espousal of normative propositions, something that James did in profusion throughout his career. John Dewey failed to make this distinction when he said that 'William James did not need to write a separate treatise on ethics, because in its larger sense he was everywhere and always the moralist.' It will be seen that some of his moralizing had a distinctively deontological tone that clashed with his maximizing ethical theory. ${ }^{7}$

11 Such a reading, although having the merit of pointing to the special character of MPML, portrays MPML as advancing a utilitarian moral theory that would be at odds with the deontological principles suffusing his other moral writings. I contend that Gale's reading of James' moral philosophy as driven by an alleged clash between normative deontological propositions with maximizing ethical principles is the fallout of his reading of the underlying conception of truth and its bearings for ethics. The difference in our 
respective reading amounts thus to a difference in our different reading of his conception of truth. While Gale reads James as equating truth with usefulness, pushing him toward an utilitarian teleology whose chief principle says "we are always morally obliged to act in a manner that maximises desire-satisfaction over desire-dissatisfaction among the actions available to us," ${ }^{\prime}$ I read James as portraying truth as a peculiar state of mind - an inventive one - whose grounding lies in the relationship of interest our mind establishes with the world. 'Interest' is for James a technical term, and unlike usefulness it has a normative grounding in how things are in the world, and not only in how we would like them to be. Its direction of fit is from the world to the mind, and yet the world that is relevant for ethics is one of our ordinary practices and shared values. Truth consists in what is interesting to notice, what is worth (and not merely useful) having and requires an active endorsement on the part of the subject, who must pay attention to its moral experiencing as it is embedded in his ordinary practices of truth- and value-giving. Being grounded in this conception of truth, ethical values do not need any teleological justification, and James' discussion in MPML of the nature of values is not intended as a foundation but rather an elucidation of their place in our practices. This aspect is connected with the refutation of Gale's reading of MPML as James' moral system: if read as a moral theory, MPML would appear rather incoherent since in it James holds a number of statements that at first blush seem incompatible. Gale would thus be right in claiming that James' self was (morally) divided between a promethean pragmatist holding a maximizing principle of optimization of goods and an anti-promethean mystic struggling to make religious and spirituals ideals respectable again in a disenchanted world. However, the alleged moral aporias contained in MPML can be met by refusing to read James' claims at face value, and investigating the rhetoric in which they are articulated. From such a reading it will emerge that James' interest is not that of grounding values anywhere, but rather that of portraying how our understanding of them is vitiated by misconceptions about our mindedness and its bearings for our moral life. Through such an investigation, we could also re-interpret Gale's claim that in other writings James employs deontological principles that are not explicitly discussed in MPML, since it will emerge in which sense James' moral instructions in the essay are directed precisely against the attempts to moralize morality and reduce moral reflection to the defense of a narrow and well-characterized picture of what counts as a moral experience.

\section{米}

12 I will argue, contra Perry, that it is not true that James was uninterested in the traditional problems and theories of ethics, since his interest was precisely a critique of their understanding. His goal was that of showing the shortcomings and difficulties of characterizing the aim of moral reflection as the achievement of a normative moral system. However, this critique makes space for another conception of moral reflection sketched in MPML, one that has a distinctive reflective status that must not to be conflated with the moral ideas pervading his other works, even if it entertains a close relationship with them. Instead, contra Gale, I will argue that in MPML James canvasses a precise picture of the entanglement between moral reflection and moral life that is neither one of mutual incompatibility nor one of reduction - one that does not lead to any utilitarian moral theory. In order to understand the nature of such an entanglement we must decrypt James' assertion that the aim of moral reflection is the clarification, and 
not the foundation, of our moral life. As James argues, an ethics must be hortatory rather than prescriptive: it must convey the unsatisfactoriness or the adequacy of a certain moral idea or conduct, and the means by which it should do that is not by pointing to some alleged principle they violate or honor, but rather by describing the assumptions on which their endorsement rests and inviting us to challenge its validity. Moral reflection should thus be descriptive rather than prescriptive, and it should be articulated along the experiences and experimentations human beings endorse in their ordinary practices. This does not mean however that moral reflection consists in a descriptions devoid of any normative element; in fact the dichotomy between the merely descriptive and normative, as well as that between facts and values, is refuted by James as a residuum of a Cartesian framework, inherited and developed in opposite directions but with same unsatisfactory results by both British empiricism and German rationalism. This refutation, whose articulation falls outside the scope of the present essay, ${ }^{9}$ allows James to portray moral reflection as an activity that is at the same time descriptive of our moral life and normatively inspired..$^{10}$ The kind of descriptions James has in mind picture human beings as agents and their moral ideas as emerging from their experiences and practices. James is describing not what human beings are, but rather what human beings do. Furthermore, he is describing not what they do according to some principle of aiming at some result, but what they do of themselves when following a certain idea or responding to a certain experience.

13 James' criticism of moral theories as pieces of moral reasoning attached from the outside to the concrete life of human beings is precisely directed against the 'illusory comfort of an external standpoint ${ }^{\prime 11}$ from which to assess our moral life. Moral reflection aims at the understanding of our moral experiences as they are displayed in our ordinary practices, and thus it must be as tentative and experimental as the moral life in which those practices take place. The criticism of a moral position cannot be made from a standpoint that is external to the moral life in which it is embedded, but only from the internal, as a failure to meet its own standards of rationality. However, far from being a concession to relativism, this is a point about the kind or realism James is canvassing. Claiming that in order to criticize a certain moral position you must be embedded in a certain form of life, that is be able to see things in a certain way, does not commit us to picture moral criticism as beyond the limit of rational discourse, since being embedded in a certain form of life is precisely what our moral criticism is about. The inability to engage in this form of criticism is what James calls 'moral blindness,' and it is connected with James' characterization of how we picture the attainment of truth in morality. So its full articulation must wait till section 8 , when the stage will be set with all the necessary elements.

14 A first indication into the anti-foundational motif of the essay is traceable in James' few but significant considerations about moral skepticism. In the second paragraph of MPML he writes that moral skepticism, or rather the ethical skeptic, is not an acceptable moral position which we can discuss at a reflective level, since by denying the very existence of a shared moral reality it cuts itself off from moral discourse altogether. He writes

[f]irst of all, what is the position of him who seeks an ethical philosophy? To begin with, he must be distinguished from all those who are satisfied to be ethical sceptics. He will not be a sceptic; therefore so far from ethical scepticism being one possible fruit of ethical philosophizing, it can only be regarded as that residual alternative to all philosophy which from the outset menaces every would-be philosopher who may give up the quest discouraged, and renounce his original aim. 
That aim is to find an account of the moral relations that obtain among things, which will weave them into an unity of a stable system, and make the world what one may call a genuine universe from the ethical point of view. ${ }^{12}$ philosophy - what here I am calling moral reflection - in the course of the essay, here he is claiming that the appreciation of a shared moral life is a precondition on which moral reflection bears, and thus that moral skepticism falls outside of the scope of the aims of MPML. The moral skeptic avoids his responsibility to take part in the moral community, and thus his attitude raises other kinds of questions and considerations than those tackled in MPML. ${ }^{13}$ In fact, in the essay James is interested in carving out what moral reflection could look like from the very inside of its exercise, wary of the commonest mistakes committed by those philosopher who understand their own reflective activity as the imposition of some order of values -whatever their nature- on reality. He continues by saying that

[t]he subject matter of his study is the ideals he finds existing in the world; the purpose which guides him is this ideal of his own, of getting them into a certain form. ${ }^{14}$

The two ideals, the one(s) guiding moral reflection -and the moral philosopher beyond itand the one(s) guiding the moral life -and the moral subjects animating it- are of different kinds, and thus the relationship between the two cannot be symmetrical. If in fact we were to throw the ideal of moral reflection inside those of the moral life it would suffocate them, smothering the moral life itself. Abstract principles of systematization, such as those expressed in moral principles, violate the very tentative nature of moral facts and experiences, as they are articulated in our ordinary moral lives. Robert Talisse and Micah Hester have beautifully put this point. While discussing James' conception of 'moral fact,' they write

[J]ames' commitment to lived experience brings with it a series of philosophical implications [...] The principal objective of radical empirical philosophy is to "return to life"; that is, to bring philosophical ideas and habits consciously to bear on our lives. Among the irreducible components of our lived experience is what we shall call 'moral experience.' That is, our daily transactions with others and the world features a decidedly moral dimension. Just as the world forces us to hold beliefs and thus to act, we are likewise compelled to make judgments, and the elements of experience that compel them, are as real as any other aspect of experience. Hence your visual experience of the ink spot on this page which comprise this very sentence is, on the view of the radical empiricist, on a par with your judgment that your favorite painting is a work of beauty, your feeling or regret at the remembrance of a missed opportunity to do good, and your repulsion to the idea of the unnecessary suffering of innocents. Unlike traditional philosophical systems, which attempt either to reduce moral experience to something more scientifically manageable such as pleasure and pain, or to elevate moral experience to something other-worldly, supernatural, and as such inexplicable, the radical empiricist bids us to confront the facts of experience directly and on their own terms. This follows from the basic tenets of radical empiricism. ${ }^{15}$

17 The authors continue by showing how it is this peculiar understanding of moral facts that allows James to portray ethics in anti-foundational terms, as an ongoing activity of rethinking our practices rather than one of trying to fix them by inscribing their possibility into some moral principle. What is at stake in moral reflection is our very 
perspective on those facts articulating our moral experiencing, and thus it should have a character that is as open as the facts it tries to account for. They write

[e]xperience is too complex and the universe is too rich and varied to allow capture by a few philosophical maxims. James rejection of the traditional philosophical aspiration for a comprehensive moral theory, however, does not constitute an abandoning of the fundamental question, How ought we to live? In fact, on James' view this question becomes all the more vital precisely because we cannot rely upon tidy philosophical theories for quick-fix solutions to moral dilemmas. We must act in the absence of moral certainty; thus, the question of how to live becomes crucial. So, how does James approach the question of how we ought to live? To answer this, it is important to recognize that James' rejection of traditional moral theory is in essence a refusal to see the fundamental concern of moral philosophy primarily upon individual acts [...] [T] he principal focus of Jamesian moral philosophy is life, not merely individual actions, and actions are on James' view the expression or manifestation of our habits, and our habits are formed from our more general attitude toward life, not towards specific events. This attitude is what James sometimes refers to as our 'mood.'16

A major outcome of this understanding of the entanglement of moral reflection and the moral life is that the focus of ethics must be the whole life of human beings: their visions and attitudes, and not only their preferences that they express at the moment of choice. ${ }^{17}$ Given that this is so, the relationship moral reflection should entertain with the moral life cannot be one of foundation. According to James a piece of moral philosophy must be suggestive rather than prescriptive: it must conveys the depths and the trivialities of our moral experiences, rather than prescribing which course of action should be appropriate accordingly to some alleged moral principle. As James writes in the introduction of Talks to Teachers on Psychology and to Students on Some of Life's Ideals

$[t]$ he science of logic never made a man reason rightly and the science of ethics (if there be such a thing) never made a man behave rightly. The most such science can do is to help us to catch ourselves up and check ourselves, if we start to reason or to behave wrongly; and to criticize ourselves more articulately after we have made mistakes. ${ }^{18}$

19 A philosophical account of morality aims at questioning the grounds of our moral practices by describing the way and the conditions through which we endorse or reject such practices. When doing moral philosophy we do something different from offering theories: we try to make sense of the practices surrounding our judgment of values and our attribution of significance. In the next section I shall venture into the very dialectic of MPML, in order to present its structure and arguments. Once read resolutely ${ }^{19}$ - and in the light of James' considerations about the nature of truth and mindedness that he explores in his writings on pragmatism and the philosophy of mind - the essay conveys a precise picture of the shape morality should take in order to entertain a profitable relationship with the moral life it should address.

\section{米}

20 James was suspicious about theories, because of their tendency to force the varieties of experiences under a single and often misleading category. What is interesting in theories is rather what lies beneath them: that is, facts. This internal resistance of facts to theories is even more significant in the ethical domain, where the 'trail of the human serpent' is more than ever pronounced. In On Some Hegelism James writes 
[i]n the exceedingness of the facts of life over our formulas lies a standing temptation at certain times to give up trying to say anything adequate about them, and to take refuge in wild and whirling words which but confess our impotence before their ineffability. ${ }^{20}$

21 The language of theories ('our formulas') is inadequate to account for the facts of life, and James denounces the 'standing temptation' to give up taking those facts in their own terms, and take refuge in words that could capture such a variety. This insight acquires the utmost importance in the ethical discourse, where moral theories have the presumption to regulate the varieties of moral facts from the outside, missing in this way the tentative character of the moral experiences in which they are embedded. MPML opens with the opposite auspice that there will be no ethical theory, and thus no ethical truth, until there will be human experiencing. Theories of morality tend to prescribe which facts are relevant for moral assessment, and how to individuate them. ${ }^{21}$ James contends that this violates our very moral phenomenology: we do not experience values as filling or fitting some pre-experiential order, and their truth responds only to human standards as they are set in the course of our practices. James writes in the opening of the essay

[t]he main purpose of this paper is to show that there is no such thing possible as an ethical philosophy dogmatically made up in advance. We all help to determine the content of ethical philosophy so far as we contribute to the race's moral life. In other words, there can be no final truth in ethics any more than in physics, until the last man has had his experience and said his say. In the one case as in the other, however, the hypotheses which we now make while waiting, and the acts to which they prompt us, are among the indispensable conditions which determine what that "say" shall be. ${ }^{22}$

Since morality, in order to specify its very contents, has to wait on experience, moral reflection will take its course from the analysis of such experiences as they are lived in the course of the moral lives in which they are lodged. According to James in ethics there are three questions that must be kept apart, and thus three kinds of investigations can be addressed in respect to our moral life: the psychological question about the origin of our moral ideas, the metaphysical question about the meaning of our moral words, and the casuistic question about the measure of goods which human beings recognize. In order to start appreciating the anti-foundational character of James' essay, it is important to notice that all these different investigations are raised about our common moral practices and not from sideways-on: these investigations make sense only because our moral life is shaped in a certain way. Had we been different from how we actually are, different questions would have arisen. ${ }^{23}$ Moral reflection will thus take its course from the inside of our moral life in order to assess its strategies, presuppositions and shortcomings. Read in this way, the central parts of the essay present various aspects of our moral life, with an overview of the difficulties peculiar to each aspect of it. The role of the moral philosopher is a descriptive one, and consists in accounting at a reflective level how we fail to appreciate this variety if we portray our moral life as the establishment of moral principles independently from our activities of endorsement and valuing the relevant moral experiences. Franzese, in the book mentioned in note 1, shares a similar antifoundational reading of James' moral philosophy, but develops this intuition in a different direction since he reads the essay in totally negative terms, while I read it as containing both negative and positive instructions. Our disagreement, at bottom, is about the method of MPML: while agreeing that James meant it not to be read as an advancement of a moral theory, Franzese reads the central sections of the essay as the demonstration of the unavoidable 'dead ends' characterizing any metaphysical, and 
casuistic foundation of morality - since, as the dialectic of those sections would show, each of the principles advanced is doomed to failure due to their clash with the aposteriori character of our moral life - I, on the other hand, read them as the discussion of the different aspects of our moral life deserving a special attention. Both Franzese and myself agree that in the essay James is critical of a certain way of doing moral philosophy as the advancement of philosophical requirements on our very moral phenomenology from the above, but while I take those sections as together an exploration and a rescue of some aspects of our moral life from a deceived way of looking at them, Franzese takes them as the exposition of three variations of the foundational project James wants to debunk. Although attractive, Franzese's reading expunges any interesting role for moral reflection, while I think that the whole point of the essay is precisely that of carving out an understanding of moral reflection that, once it has lost its foundational aspirations, is congenial to the character of our moral lives. ${ }^{24}$ I shall now sketch how James accomplishes that in the essay.

The psychological question examines the nature of our moral ideas, whereas under this label James groups both our moral perceptions and our moral sensibility. This question has been explored in depth by both the intuitionist and the evolutionist school. James pays tribute to the associationist tradition for its emphasis on the empirical roots of our moral distinctions, however criticizing the idea that the mechanism of association exhaust all there is to say about the nature of moral ideas. There are, in fact, many ideas that cannot be described in terms of mere association between states of affairs and simple sensation of pleasure or pain. James writes that,

[t]he more minutely psychology studies human nature, the more clearly it finds there traces of secondary affections, relating the impressions of the environment with one another and with our impulse in quite different ways from those mere associations of coexistence and succession which are practically all the pure empiricism can admit. ${ }^{25}$

24 The same could be said of our moral perceptions, whose importance in James' ethics cannot be underestimated: "[a] vast number of our moral perceptions [...] deal with directly felt fitness between things, and often fly in the teeth of all the pre-possessions of habit and presumptions of utility." ${ }^{26}$ James is claiming that our moral ideas and perceptions have a special cognitive character that cannot be reduced to considerations of utility assessed on the basis of past experiences. Moral ideals bring with them an element of novelty, because it is only through embracing them that we envision the distinctive character of a certain situation. For example, betrayal, from a detached description, would include both the facts involved and their consequences - in terms of pleasure and pain - on the subjects involved, but not, for example, its character of seriousness. What has gone missing is the distinctive contribution that our endorsement of such an idea or perception confers on their moral character. The examples of these secondary perceptions given by James are diverse, spanning from 'the sense for abstract justice, the passion for higher philosophical consistencies, the feeling of the inward dignity of certain spiritual attitudes and of the essential vulgarity of others.' James writes

[t]he nobler thing tastes better, and that is all that we can say. "Experience" of consequences may truly teach us what things are wicked, but what have consequences to do with what is mean and vulgar? ${ }^{27}$

That one state of affairs (or an action) is wicked or wrong can be told just by looking at the consequences of its happening, while that something is mean or vulgar can be told only by looking at how that situation appears to someone with a certain character - one 
who can taste its ignobility. This distinction between the evaluation we can give of a certain state of affairs (or an action) on the basis of its consequences, and the one we can give according to the character of the agent has immediate ethical consequences: while in the first case we refer to states of things or actions (roughly: outcomes) and their relationship with some alleged principle (of goodness or rightness), in the second case we refer to what the subject envisions and how he pictures the situation in hand or the action. James portrays this contrast as one between the evaluation of how things or action are - in terms of their consequences - and how one sees them - in terms of the involvement the subject has with the situation or the action in hand. In the one case we merely describe how things are arranged or which actions are undergone and evaluate them according to some principle (as for example the association of such states of affairs or actions and sensations of pleasure and pain felt in past experiences), while in the other we describe how a person arranges things together or which action is expressive of one's stance in respect to the relevant situation. According to James, the importance of these thick ${ }^{28}$ ethical concepts consists not only in their being descriptive, but rather in the kind of description they provide of a certain situation or action. Ethical concepts do not merely mirror some past experiences, but rather their endorsement helps create the peculiar moral character of the situation under description. To take the case of courage: by picturing a certain conduct as courageous we do not merely describe what a courageous person ought to do in a certain situation, but also the very stance that person has on the relevant facts, which determines their worth. By being courageous an agent establishes the truth conditions of a certain moral evaluation, since it is only when a courageous stance is actively endorsed that the moral salience of a certain situation become assessable. It is this very agential description that is out of view from a detached perspective in which what we describe are merely the consequences of a certain idea and their relation with the past experiences in which that idea has been realized in order to assess its value.

James is claiming two things at once: he is both claiming that all consequences can tell us is how present experiences relate with past ones while instead moral ideas are also future oriented, and that, in virtue of this fact, moral ideas or perceptions are not merely copies of past experiences, but rather they are more the expression of the peculiar stance we can take on future experiences. James articulates these points by saying that

[p]urely inward forces are certainly at work here. All the higher, more penetrating ideas are revolutionary. They represent themselves far less in the guise of effects of past experience than in that of probable causes of future experience, factors to which the environment and the lessons it has so far taught us must learn to bend. ${ }^{29}$

27 For our discourse it is important to note how James shifts the terms of the psychological question from those in which it has been framed in modern moral philosophy: the opposition is not one between experiences and intuitions, but rather one between different genealogies about how values are grasped within experience. According to both classical empiricism and intuitionism this aspect of morality is portrayed in terms of discovery, that is by showing how our moral notions results either from how facts are arranged together, or from some alleged special sense through which we grasp their character. On the other hand, according to James' radical empiricism this aspect of morality is portrayed in terms of invention, that is by showing how our moral notions represent the kind of stance we can take toward certain facts. James claims that the proper source of moral value lies within one's capacity to take a peculiar stance toward the relevant aspects of the world. Here James, as it will become clearer later in the essay, 
is not claiming that we are the sources of values - as the majority of readers misleadingly interpreted him -, but rather that the capacity to grasp values depends on us. It is by acting in the relevant ways that we pay tribute to the values of certain aspects of the world, which but for such an active endorsement would be idle. According to James, values, like facts, are in the world, but it is only when a peculiar engaged stance is endorsed that their reality is fully in place. Actions and agency are not internal happenings, but rather they are factive bearings on the world. Thus, the moral proprieties to which we refer when making moral judgments and performing moral actions do not take their value from some internal happenings - such as a projection of our sentiments or feelings on a brute world -, but rather their exercise in the world creates the conditions of moral value. James portrays this agential stance as inventive, and contrasts it with an unengaged one according to which the origin of our moral ideas is portrayed as an instance of discovery. ${ }^{30}$ Why this stance has to be inventive, and how it relates with the truth of the facts experienced, is addressed later in James' essay within the discussion of the other two aspects of moral reflection. Let me now pass to the exposition of the second aspect: the metaphysics of moral words.

The importance of words and language in morality has been the main preoccupation of moral philosophers working in the analytic tradition, especially in its first fifty years of life. A major theme running through this tradition is the idea that by investigating the ways in which we talk and the words we use it could be possible to understand the character of our moral ideas. The leading idea beyond the so-called linguist turn was that philosophical problems were at bottom linguistic problems, so that by investigating moral language - intended as a peculiar strand of the larger linguistic discourse - we could unravel the nature of our moral life. ${ }^{31}$ James shares the concern for the way in which our words and language shape our philosophical inquiries and our lives. In the Principles James claims that the reason beyond a distorted comprehension of our mental phenomena lies in the use of an inappropriate language to describe it. Since the language we employ in describing both ourselves and our experiences is dominated by nouns and refers primarily to objects, we have a distorted perception of both. James' diffidence toward language springs from its inability to account for the personal and fringe character of experience; in fact both our subjective states and the description we use to refer to our practices of knowledge are expressed in a language that hides their nature, a language which, by resembling the middle-sized objects of the outer world, is at risk of jeopardizing the very nature of our experiencing. James complains that "[i]t is hard to focus our attention on the nameless, and so there results a certain vacuousness in the descriptive parts of most psychologies." ${ }^{32}$ The empiricist tradition is responsible for the idea according to which for every discrete mental state there is a word corresponding for it; so conceived, language would form a comprehensive description of our inner life. However, this conception of language overlooks the fact that introspection reveals a stream of sensations and thoughts that are not reducible to what James calls 'an atomist, brickbat plan of construction of the mental.' Regarding the vocabulary we use to describe our inner states the problem is that, as Gerald Myers wrote:

[t] he lack of a descriptive word can cause us unwittingly to overlook what is subjectively present, thus neglecting what may be familiar to all of us if we had grown up with the appropriate words..$^{33}$

I want to argue that James was well aware that in the moral case we have an analogous complication, and in the discussion of what he calls the metaphysical question he tackles directly this theme concerning moral language. James' treatment is pivotal for the 
understanding of his conception of moral though as the clarification of our moral life. Our words and language are in fact revelatory of our moral life, and there is a sense in which our life with words itself is a moral issue. This theme is approached by James in two steps: first by showing the metaphysics underlying our moral terms, and then by discussing its plausibility. James begins by noticing how the words obligation, good and ill 'have no application or relevancy in a world in which no sentient life exists'; such words are empty and meaningless in a world without any 'interested spectator.' I want to remark that James' emphasis here is not on mere sensitivities, as the vast majority of scholars have argued, but on activity itself. In a world without human beings there could be no moral notions since nobody would exercise them. Moral sensibilities are important but only in their very exercise and realization. James claims

[g]oodness, badness, and obligation must be realized somewhere in order really to exist; and the first step in ethical philosophy is to see that no merely inorganic "nature of things" can realize them. Neither moral relations nor the moral law can swing in vacuo. Their only habitat can be a mind which feels them; and no world composed of merely physical facts can possibly be a world to which ethical propositions apply. ${ }^{34}$

30 In this quotation there are listed all the ingredients of James' metaphysics of values, which, far from being a 'metaphysics' in the traditional acceptation of the term, is rather a metaphysics ex parte subiecti. James in fact argues for his view by means of a series of thought experiments - which many commentators have seen as close to the ones Wittgenstein made in the sections of the Investigations discussing the 'private language argument' - which, instead of laying down some theoretical principle of meaningfulness for our moral words, indicates how we come to give moral significance to them, and how those words are revealing of our moral life. James claims that moral words have meaning only when there is an activity of evaluation lying beneath them; that is only when human beings exercise their sensibilities by responding to the relevant aspects of the world animating them. According to James the truth of moral ideas is not independent from our thinking them under certain conditions. Furthermore, his interpretation of the Peircean conception of belief as willingness to act is consistent with the idea that it is only by actively endorsing a certain value that we establish its reality and truth conditions..$^{35}$ This amounts to the claim that the foundation of the metaphysics of values lies in our being agents. However, this conclusion is not the result of a transcendental argument. This is clear as we move to the second step of James' argument, which assess the plausibility of this achievement by showing its grounding in our concrete moral life.

31 Once it is argued that moral words have a metaphysical footing in the exercise of our sensibility, James wants to show that this does not commit one to epistemological and moral solipsism. To do so James, introduces the other key word in our moral vocabulary: namely, obligation. Once again, his method for assessing its meaning is that of exhibiting its place and weight in our practices. He asks us to imagine a universe inhabited by only one human being, and wonders whether in this scenario moral relations would hold or not. His answer is peremptory:

[i]n such an universe as that it would of course be absurd to raise the question of whether the solitary thinker's judgments of good and ill are good or not. Truth supposes a standard outside the thinker to which he must conform. ${ }^{36}$

This statement could sound untuned, given what has been said so far. Is James inconsistent here with his previous thoughts, as many commentators have noted while reading this passage? How is it possible to claim at the same time that we help establish 
the reality of moral notions, and that their truth also requires a standard outside the thinker to which they must conform? The answer to these questions is built into the second part of the though experiment, in which James goes on by asking us to imagine another universe, now with two human beings - but the same will hold for any $n+1$ universe. Now if they ignore each other by being indifferent to their respective attitudes we would have a 'moral dualism' in which 'no one objective truth, but only a multitude of subjective opinions, can be found.' However, this is a quite unsatisfactory situation as well, since as in the solipsistic scenario, there would be no morality in a robust sense at all. So far our situation is the following: on the one hand we have established that moral relations depend on the exercise of our sensibilities, and on the other we have admitted that such a metaphysical grounding is not sufficient per se to the achievement of a moral community. James' solution to this puzzle lies in the characterization of obligation as a concrete feature of reality realized in our lives, as contrasted to an abstract principle 'floating in the atmosphere.' We fall into the above inconsistency only if we picture morality in theoretical terms, as the abstract comparison between the worth of different states of affairs. If otherwise we conceive moral obligation in practical terms, that is as the expression of the claims actually made by human beings, we can hold together the idea that the exercise of our sensibilities is the source of moral notions and that their truth conditions are not exhausted in their abstract conceivability or desiderability. James writes,

[1]ike positive attributes good and bad, the comparatives ones better or worse must be realized in order to be real. If one ideal judgment be objectively better than another, that betterness must be made flesh by being lodged concretely in someone's actual perception [...] Its esse is percipi, like the esse of the ideals themselves between which it obtains. ${ }^{37}$

Here James is refuting a deceptive picture of morality whose a priori character clashes with the a posteriori character of our concrete moral lives. In order to grasp the nature of moral claims we must look to the way persons actually hold their moral notions and question those of others. However, James acknowledges the existence of some impediments that endanger our comprehension of the nature of our attribution of values - some of which are of a linguistic nature. In this direction James writes that

[t]here is an inevitable tendency to slip into an assumption which ordinary men follow when they are disputing with one another about questions of good and bad. They imagine an abstract moral order in which the objective truth resides; and each tries to prove that this pre-existing order is more accurately reflected in his own ideas that in those of his adversary. It is because one disputant is backed by this over-arching abstract order that we think the other should submit. ${ }^{38}$

This human tendency can be contrasted by an accurate description of the way in which such attitudes arise. According to James there is a close correspondence between moral claims and obligations, since

[t]he moment we take a steady look at the question, we see not only that without a claim actually made by some concrete person there can be no obligation, but that there is some obligation wherever there is a claim [...]. Every de facto claim in so far forth? an obligation. ${ }^{39}$

However, it is hard to realize such an identity since we tend to reverse the order of logical priority between a claim and its obligatory weight. In fact we are prone to think that before advancing a claim we have to assess the conditions of its moral legitimacy, but this means picturing the validity of the claim, and thus its obligatory character, as depending on something additional to its mere existence. But what else, James asks, could count as 
an obligation if not something actually desired? The point here is metaphysical: before something is actually claimed, there is nothing on which obligation can intervene. According to James' moral psychology, it is interest and not desires or pleasure that lies at the cornerstone of our moral psychology: interests denote the activity of attention to those facts which fit our mental structure and so arouse positive feelings of adequacy between mind and world. It is because there are certain facts in the world prompting one's sensibility (through the mechanisms of selective interest plus attention) that one acts in a certain way and feels the relevant pleasure. According to this picture morality will thus consists in acquiring the relevant ideas by being attentive to the relevant facts. In such an understanding moral objectivity, a "standard outside the thinker," will arise only if there is a demand for it. And such a demand will arise only if the sentient beings in the universe, rather than being indifferent to one another, respond to their respective demands. James writes

[t]he only force of appeal to us, which either a living God or an abstract ideal order can wield, is found in the "everlasting ruby values" of our own human hearts, as they happen to beat responsive and not irresponsive to the claim [...] Wherever [actually living] minds exist, with judgments of good and ill, and demands upon one another, there is an ethical world in its essential features.$^{40}$

Goods are constituted by demands, and moral objectivity is a matter of taking account of such demands by being responsive to them. James argues that to ask for an external legitimacy of objectivity means missing the very point of advancing a claim: the only thing that could hinder the endorsement of a claim is another claim. This brings us straight to the casuistic question, whose subject matter is the analysis of our ways of weighting claims and goods.

It is by discussing this aspect of morality that James' criticism of moral theory appears more clearly. His dissatisfaction with ethics conceived 'in the old-fashioned absolute sense of the term' is due to its theoretical, as opposed to practical, inspiration. In this section James reflects on the role of the moral philosopher in facing the moral disagreements spreading in our societies. James observes that the philosopher's aim is that of getting 'a system of truth' among moral ideas. Given the multiplicity of values claimed in our pluralistic societies, James concludes that the most acceptable moral principle is that whose endorsement could satisfy as many demands as possible at the least cost. This utilitarian inspired conclusion, however, seems a dead end as an answer to the casuistic question, unless we characterize what kind of moral principle it provides. James takes into consideration the strategies adopted by the most important schools of philosophy, and claims that they share an underlying principles: they think that the solution to the casuistic question can be resolved by reducing the varieties of goods claimed to some more simple categories, since, in this scenario, if

[i]t were found that all goods quâ goods contained a common essence, then the amount of this essence involved in any one good would show its rank in the scale of goodness, and order could be quickly made. ${ }^{41}$

James finds this solution - variously advanced by intuitionism, hedonism, divine law, and even Darwinism - quite unsatisfactory because of their common description of a society whose morality is already inscribed in some abstract principle to which our mind ought to aim - this being what we intuitively grasp, what would pleasure us, what the divinity we are committed to command us, or what fits best for our survival. However, according to James this is a paltry description of the place of truth in our moral lives, since it pictures the truth of our moral claims as grounded on something outside experience, 
conferring on it a normative character. Further, it contrasts with our very moral phenomenology, which, given the varieties of claims expressed in our moral experiences, can barely accept the existence of a single scale of evaluation. James writes

[t]he elementary forces in ethics are probably as plural as those of physics are. The various ideals have no common character apart from the fact that they are ideals. No single abstract principle can be so used as to yield to the philosopher anything like a scientifically accurate and genuinely useful casuistic scale. ${ }^{42}$

James claims that a way out of the casuistic dilemma can be envisioned only by getting rid of this image of morality as the struggling for an abstract principle of goodness. The casuistic question is 'tragically practical' - since, as James notes, if it was only a theoretical problem about 'imaginable systems of goods' it would hardly have been raised at all, and thus its resolution should be practical as well. However, James argues that what hinders us from pursuing this resolution is the fact that

$[w]$ e are blinded to the real difficulty of the philosopher's task by the fact that we are born into a society whose ideals are largely ordered already. If we follow the ideal which is conventionally highest, the others which we butcher either die and do not return to haunt us; or if they come back and accuse us of murder, everyone applauds us for turning to them a deaf ear. In other words, our environment encourages us not to be philosophers but partisans. ${ }^{43}$

Moral principles, when we think of them as the outcome of a society whose values are already fixed outside experiencing, lead to moralism and parochialism, which are the two extremes of the very same intellectualistic and foundational conception of morality. It is in this context that James advances the alleged utilitarian principle of maximization, which, uncritically taken, is displayed as James' grounding moral principle. James actually claims that

[s]ince everything which is demanded is by that fact a good, must not the guiding principles for ethical philosophy (since all demands conjointly cannot be satisfied in this poor world) be simply to satisfy at all times as many demands as we can? That act must be the best act, accordingly which makes for the best whole in the sense of awakening the least sum of dissatisfaction. In the casuistic scale, therefore, those ideals must be written highest which prevail at the least cost, or by whose realization the least possible number are destroyed. ${ }^{44}$

However, this principle is useless if we do not grasp the implications James draws from it. James' suggestion is that we have to rethink our relation to this moral principle as an inventive one, in which the truth of our moral ideas is established by inventing the conditions for their actual realization. He writes

$[t]$ he course of history is nothing but the story of men's struggles from generation to generation to find more and more inclusive order. Invent some manner of realizing your own ideals which will also satisfy the alien demands - that and that only is the path of peace! Following this path, society has shaken into one sort of relative equilibrium after another by a series of social discoveries quite analogous to those of science. ${ }^{45}$

Ethics requires experimentations, and like physical science it has an a-posteriori character. However, unlike scientific discourses, ${ }^{46}$ its advancements consist in the questioning of past empirical results and the way in which they were understood by the subjects involved. What matters in the formation of our moral ideas is precisely the way in which our interiority responds to their emergence or decline. He writes

[t]he presumption [...] always is that the vulgarly accepted opinions are true, and the right casuistic order that which public opinion believes [...] Every now and then, however, someone is born with the right to be original, and his revolutionary 
thought or action may bear prosperous fruits [...] He may, by breaking old moral rules in a certain practice, bring in a total condition of things more ideal than would have followed had the rules been kept. ${ }^{47}$ the truth of a certain way of seeing things and being dissatisfied with opposite visions. This claim, made in the context of James' investigation of the role of truth in the articulation of philosophical reflection, can be very instructive for understanding the place of the notion of truth in our moral lives. Truth here refers to the kind of stance we can take toward experiencing altogether, one in which we actively commit to the reality of a certain experience due its capacity to bring us into a satisfactory relation with the world. Given this first characterization of truth, James goes on to investigate the way in which such a satisfactory relation can be realized, and the very psychology of the agents 
involved. The picture he is resisting is one in which truth stands for the static property of our thoughts to represent reality as we find it independently of our human interests, demands and cravings. He writes

[t]ruth independent; truth that we find merely; truth no longer malleable to human need; truth incorrigible, in a word; such truth exists indeed superabundantly or is supposed to exist by rationalistically minded thinkers; but then it means only the dead heart of the living tree, and its being there means only that truth also has its paleontology and its 'prescription,' and may grow stiff with years of veteran service and petrified in men's regard by sheer antiquity. ${ }^{51}$

Against this characterization James advances a picture in which truth is the very expression of our interests, demands and cravings. He contends that ideas become true insofar as they are endorsed and lived by. There is a plasticity in our experiencing in which new and old truths fight as opposed working values that we advance to get a satisfactory image of reality. The identification of truths with goods is dictated by the very nature of true ideas: truth stands for the active commerce between particular thoughts and experience, whose nature is not one of usefulness but rather one of satisfaction. James writes

[t]ruth is one species of good, and not, as is usually supposed, a category distinct from good, and coordinate with it [...] [i]n this world, just as certain foods are not only agreeable to our taste, but good for our teeth, our stomach, and our tissues; so certain ideas are not only agreeable to think about, or agreeable as supporting other ideas that we are fond of, but they are also helpful in life's practical struggles. 52

[t]he truth is the name of whatever proves itself to be good in the way of belief, and good, too, for definite, assignable reasons [...] [I]f there be any life that it is really better we should lead, and if there be any idea which, if believed in, would help us to lead that life, then it would be really better for us to believe that idea, unless, indeed, belief in it incidentally clashes with other greater vital benefits. ${ }^{53}$

These are among the passages that have been most fiercely attacked by James' critics, who have read into them the identification of truth with mere usefulness, laying down in this way the foundation for the reading of his moral philosophy as a defense of a hedonistic variant of utilitarianism. Since true ideas are those which we are pleased to believe, they say, moral truths consist in what we found pleasant to gain. However, only a few lines below we found James saying something that undermines such an interpretation and opens the way for more imaginative reading of his position. James recognizes that his position could appear rather awkward, but only if truths are taken in the abstract sense, as a hypothesis not grounded in our concrete claims to experience. But 'it is evident that something happens when you pass from the abstract to the concrete, that complicates the situation'; in fact, when truths are made flesh the biggest hindrance they could encounter are other truths resisting them, truths claimed by other human beings or by ourselves at earlier times. In fact vindicating the human trail on our practices of truth does not to commit James to any idealistic epistemology, since he presents the footing of truths as always grounded in our concrete experiencing. James characterizes true ideas as those that we can 'assimilate, validate, corroborate and verify': "[t]ruth is made, just as health, wealth and strength are made, in the course of experience. ${ }^{\prime 4}$ According to this picture of truth, our mind is always engaged in the attainment of truth. Our attitude toward truth is not the static one of mirroring evidences, but rather that of questioning their 'cash-value in experiential terms.' We ask not 'given these evidences, am I justified in calling them true?,' but rather 
[g]rant an idea or belief to be true [...] what concrete difference will its being true make in anyone's actual life? How will the truth be realized? What experiences will be different from those which would obtain if the belief were false? ${ }^{55}$

The contrast I am interested in stressing is between a live as opposed to a dead stance we can take toward experience and thus toward truth. James portrays this contrast by saying that the reasons for the establishment and recognition of a certain truth are always reason for action as guided by truth. Our agency is expressive of the truths we help establishing, since we use such and such truths as the very background for our practices. As James writes, "[o]ur duty to gain truth, so far from being a blank command from out of the blue, or a 'stunt' self-imposed by our intellect, can account for itself by excellent practical reasons. ${ }^{56}$ We have truths because we find some objects or idea important and worth having; truths are expressive of our interests and cravings, and there is no point of calling a certain idea true if we were insensible and unconcerned for its reality. To this extent truths are the result of the peculiar posture that our minds can take on reality, and their establishment is set by an act of endorsement that in its turn is shaped according to our practical needs. James makes the point by saying that "[b]y our inclusions and omissions we trace the field's extent; by our emphasis we mark its foreground and its background; by our order we read it in this direction or in that." ${ }^{57} \mathrm{In}$ The Meaning of Truth James explores this idea by showing in which sense the practical stance from which we assess truths is inventive. James quarrels about the meaning of the expression 'agreement with reality,' which is proposed by his opponents as the key to understanding the nature of truth. He accepts it but widens the boundaries of what 'agreement' amounts to in a direction that is congenial to our discourse. He claims that truth is not merely duplicative of reality, since the copy of reality is only one among many of our interests. What is at stake in our experiencing is the attainment of a fruitful relation with reality, be it one of copying or not. That of agreement is a wider notion than both empiricists and rationalists were ready to admit. The problem with both empiricism and rationalism is that they tried to "weed out the human contribution" from the process of agreement, picturing it either as the passive exposition of our senses to facts or as the exemplification of an extra-empirical and necessary accordance between our minds and Reality. If we get rid of the picture of truth as a relation between our mind and a nonhuman - rational or brute - reality, in favor of one in which it is the outcome of our active commerce with reality, we will achieve the possibility to see how those truths are at the same time the expression of our subjectivity, and objectively assessable by reference to reality. Our claims of truth are the expression of our point of view on experience and their validity must be assessed from within experiencing itself, resisting the temptation of postulating any external guarantee for their validity. James claims that

[m]y universe is more essentially epistemological. I start with two things, the objective facts and the [truth] claims, and indicate which claims, the facts being there, will work successfully as the latter's substitutes and which will not. I call the former claims true. ${ }^{58}$

James is not denying that reality is independent from us, but denying that truth is, since it depends on the very stance we take toward reality. It is our interests and visions that direct our investigations and determine the truth of certain ideas. There is no outside standard of truth we ought to follow except that which we establish ourselves in the course of experiencing. This practice is an inventive one since through experiencing we re-arrange facts in different and before unimagined ways according to our interests. We invent new truths by noticing overlooked similarities between situations and 
discriminating differences among the things that were unnoticed before. According to this picture

[r] eality is an accumulation of our own intellectual inventions, and the struggle for 'truth' in our progressive dealings with it is always a struggle to work in new nouns and adjectives while altering as little as possible. ${ }^{59}$

The only resistance possible to this process is an internal one, and is represented by previous truths and those held by other human beings. This theme has been explored by James in different directions ${ }^{60}$ but what interests me here are the ethical consequences of this characterization of truth as invention. This inventive conception of truth is relevant for ethics since its denial leads to what James has called moral blindness.

This characterization of truth as invention stands in opposition to blindness intended as a state of mind in which we are unable to establish a meaningful contact with the world and with other fellow humans due to our unengaged stance. In the essay On a Certain Blindness in Human Beings James argues that our judgment concerning the worth of things depends on their hold on our sensibility, and denounces the dangerousness of such a recognition, which brings with it the incapacity to enter imaginatively in alien visions and values. This moral blindness consists in a conative as well as in a cognitive failure, since when we are morally blind toward others' needs, values and truths we are not only unable to make sense of their visions and struggles but also of the realities these attitudes generate. We are blind toward pieces of reality itself, those envisioned by the truth claims of other human beings. This has tremendous ethical consequences. James remarks

[h]ence the stupidity and injustice of our opinions, so far as they deal with the significance of alien lives. Hence the falsity of our judgments, so far as they presume to decide in an absolute way on the value of other persons' conditions or ideals. $^{61}$

This failure is presented by James as a failure to occupy an engaged point of view toward the experiencing of others, and toward our own as well. In fact, when we portray a certain experience without questioning the meaning that that very experience has for the subject having it, we miss its very truth and significance. The spectator's disengaged stance toward a certain experience condemns her to miss the truth expressed in that experience. According to James there is a deep entanglement between knowing truths and feeling experiences, since in order to make an experience come alive in our mind we have to imagine what it means to endorse it as truth. In order to mark a contrast between an engaged and a detached stance towards truths, James says

[t]he spectator's judgment is sure to miss the root of the matter, and to possess no truth. The subject judged knows a part of the world of reality which the judging spectator fails to see, knows more while the spectator knows less; and, wherever there is conflict of opinion and difference of vision, we are bound to believe that the truer side is the side that feels the more, and not the side that feels the less. ${ }^{62}$

We are morally blind when we fail to see how the sources of truth are nested in the very meaning those experiences have for those who have them. When we fail to realize this fact, our perception of reality itself is poor and our judgment about it restricted. The essay presents a series of examples taken from literature and personal records in which there is a failing in grasping the nature of truth claims caused by a unengaged or dead 
stance toward alien experiences and meanings, and in the conclusion James draws a lesson of method which echoes the very closing of MPML. Let me quote both:

[h]ands off: neither the whole of truth nor the whole of good is revealed to any single observer, although each observer gains a partial superiority of insight from the peculiar position in which he stands [...] [I]t is enough to ask of each of us that he should be faithful to his own opportunities and make the most of his own blessings, without presuming to regulate the rest of the vast field. ${ }^{63}$

[b]ooks on ethics, therefore, so far as they truly touch the moral life, must more and more ally themselves with a literature which is confessedly tentative and suggestive rather than dogmatic - I mean with novels and dramas of the deeper sort, with sermons, with books on statecraft and philanthropy and social and economical reform. Treated in this way ethical treatises may be voluminous and luminous as well; but they never can be final. ${ }^{64}$

Both quotations warn us to beware of unimaginative and narrow understandings of the way in which our moral life is animated by the notion of truth. The conclusion of On a Certain Blindness invites us to pay attention to the varieties and plurality of ways in which experiences speaks to us, while the closing of MPML, given this characterization of moral truths, stresses the anti-foundational and elucidative character of moral reflection. In the essay What Makes a Life Significant James brings even tighter these two instructions by opposing the inventive stance of truth to the one of intolerance characterizing moral blindness: an epistemological failure amounts to a moral failure, and vice versa. The opening of the essay is trenchant:

[i]n my previous talk, 'On a Certain Blindness,' I tried to make you feel how soaked and shot-through life is with values and meanings which we fail to realize because of our external and insensible point of view. The meanings are there for the others, but they are not there for us. There lies more than a mere interest of curious speculation in understanding this. It has the most tremendous practical importance. I wish that I could convince you of it as I feel it myself. It is the basis of all our tolerance, social, religious, and political. ${ }^{65}$

A vivid way to make this point is James' example of the lover's perception of his beloved: when we do not appreciate the beauty that a lover sees in his beloved, James argues, we fail to appreciate something that is true. Our failing consists in the inability to grasp the reality of a state of affairs that is claimed and endorsed as true by someone, who responds to the truth of his ideas by taking them seriously. Our blindness is a failure to understand the way in which truths are recognized, endorsed, and lived by. In the second part of the essay, after another round of scenes of instruction about a variety of different conducts of life taken from personal experiences and literary works, James suggests we read such conducts as expressive of moral truths. The different lives of human beings are guided by different moral truths, which James here calls 'ideals.' Ideals are what prompt our agency to commitment, and their perception prompts us to appraise them and legitimate their validity. To understand an ideal means to understand a person's vision, and make sense of his actions and experiences. James' characterization of ideals is twofold:

[a]n ideal [...] must be something intellectually conceived, something of which we are not unconscious, if we 'have it; and it must carry with it that sort of outlook, uplift, and brightness that go with all intellectual facts. Secondly, there must be novelty in an ideal, - novelty at least for him whom the ideal grasps. Sodden routine is incompatible with ideality, although what is sodden routine for one person may be ideal novelty for another. ${ }^{66}$

These two features of ideals represent the two poles around which all the dialectics of MPML turns: ideals and truths are states of mind that must be actively endorsed in order 
to exist, and their grasp requires novelty and invention. Ideals express the kind of engagement we take in our experiencing, and characterize our intellectual as well as our affective life. Ideals are novel in the sense that their establishment consists in a creative act, and the failure to commit to the reality of ideals denotes a deficiency in one's moral life. Such a deficiency is not merely sentimental, but also cognitive, because in being blind toward the reality of ideals we are blind toward aspects of the world whose significance requires our active engagement. Ruth Anna Putnam, in stressing the cognitive character of the novelty of ideals and its relevance for the ethical life, writes that "[o]ne's ideals may contain novelty in a second sense; one may envisage changing the world, changing the way the world would go without one's intervention. ${ }^{67}$

By actively endorsing some ideals, and the truths they convey, we help to shape the values circulating in the world. Without such an active endorsement such values would be frustrated. The establishment of the truth of a certain moral idea(l) requires one's taking an active stance toward the relevant experiences, and James' instruction, far from being a prescription about what kind of idea(l)s to promote, is rather an exhortation to acknowledge their grounding in the pragmatic conception of truth as invention. By endorsing some values over others we make a choice that is of ethical significance, and the role of moral reflection is precisely that of indicating the inventive character of such an endorsement in order to dissolve the difficulties arising when we unwittingly portray it as a move that does not involve a personal contribution on our part.

In the former two paragraphs I've sketched the dialectic of MPML and James' theory of truth animating it, claiming their deep intertwinement. In this paragraph I will try to show in which way the anti-theoretical inspiration of the essay is entangled with the idea of truth as an inventive state of mind that involves the active engagement of one's interiority. Hilary and Ruth Anna Putnam, both in their individual works and in their joint articles on James, have stressed this intertwinement and portrayed it as James' major concern and most important achievement. In an interesting essay on some of James' philosophical ideas, they write that "[e]arly and late, James' motivation [...] was ultimately ethical, and his essays [...] particularly "MPML," can play a key role in understanding both his pragmatism and his radical empiricism." ${ }^{68}$ In the essay they draw a compelling picture of how James' pragmatism informs his moral philosophy, and present it by saying

[J]ames (as well as Dewey) takes the same approach to ethics as he does to common sense and science. Here too, he thinks, there are procedures which can be imperfectly characterized and which might be improved in the course of ethical inquiry itself. What is not available is a set of final ethical truths or a method by which they can be discovered. He tries to change our philosophical sensibility, rather than to replace one foundationalist ethical project with another, on the one hand, or to convince us that ethics is "non-cognitive," on the other. ${ }^{69}$

59 The authors refuse a foundational reading of MPML, and suggest that what James is trying to do is not to convince us about the validity of one theoretical option over another, but rather he is trying to change our philosophical - and, most precisely, our ethical - sensibility and expectations, in order to understand 'how best to proceed in ethical inquiry.' It has been my contention that the way he suggests we proceed is by unraveling our biased assumptions about our mindedness and worldliness, that is 
investigating how our moral life is informed by the notion of truth as an inventive mental state. Here I want to spell out at some greater length the more substantive aspects of this claim; namely, the idea that our interiority is touched and changed by the ways in which we pursue truths, and consequently its bearing for ethics.

James dedicates many pages of the Principles to the discussion of how our mental - or inner - life is profoundly affected by the experiences we undergo and the ideas we entertain. In the texts discussed James insistently returns to this idea by claiming that the ethical question 'how ought I live?' does not merely - nor principally - ask which particular actions one should entertain, but rather 'what mental perspective on the facts should I take?,' or 'which truths should I consider as the background of my experiencing?' Such questionings do involve a re-description of our mental life as a move directly relevant for the articulation of one's ethical life. James once remarked in this direction that 'thinking is the fundamental moral act' since 'a moral act is one which follows from the acquisition and possession of adequate ideas. ${ }^{70}$ For James, holding something as true requires the exercise of one's sensibility and understanding, and in moral discourse, as the dialectic of MPML shows clearly, this entanglement is presented as the condition of possibility of seeing moral reflection as a form of clarification of our moral life through a clarification of our life with our moral truths. Ethics deals with truth since it is expressed in how we perceive and describe ourselves, in how attentive and faithful we are to our visions and reactions. Registering what appears as valuable requires in the first instance a kind of re-appropriation of the space of subjectivity. Our life with truths, more than truth itself, is the primary concern of James, and in MPML this theme is articulated through the idea that the proper target of moral reflection is our very understanding of the way in which we represent the truths informing our moral lives - for examples, those concerning the metaphysical status of our moral ideas or the kind of relationship we entertain with some moral principles. James claims that we are accustomed to a superstitious view we must get rid of; he writes

[o]ur ordinary attitude of regarding ourselves as subject to an overarching system of moral relations, true "in themselves," is therefore either an out-and-out superstition, or else it must be treated as a merely provisional abstraction [...] [w]e inveterately think that something which we call the 'validity' of the claim is what gives to it its obligatory character, and that this validity is something outside of the claim's mere existence as a matter of fact. It rains down upon the claim, we think, from some sublime dimension of being, which the moral law inhabits, much upon the steel of the compassion-needle the influence of the Pole rains down from the starry heavens. ${ }^{71}$

61 The aim of moral reflection is that of ridding ourselves of this and related superstitious views, and the companion foundational anxieties according to which the moral life is exemplified in a series of moral principles that we can either fail or succeed in respecting. By claiming that what must change is our very attitude or sensibility, James re-orients the whole purpose of moral reflection, shifting the center of interest from moral theory to the self's relationship with morality itself. The pragmatic underpinning of this picture of moral reflection grounds unsurprisingly on the kind of relationship we establish with the values and truths articulating our moral lives. This image of philosophy and of the attainment of truth as animated by our moral concern brings to the fore the semantic ambiguity of the term 'ethics' in all its tension: in James' thought a conception of ethics as the inquiry into what is valuable - that however is not limited to the expression of what we would naturally conceive as moral judgments - coexists with a conception of the 
peculiar engaged stance we should assume toward experience as a whole, as opposed, for example, to the detached stance of science. The two meanings are deeply intertwined for James, since being value-blind is a direct consequence of occupying the wrong stance or attitude towards experience. This polysemy of the term ethics conveys a conception of moral reflection as involving a change from a detached to an engaged perspective toward ourselves and the world, a recovering from blindness, and the acknowledgement of the importance of the cultivation of one's attention and scrutiny of the truths animating the ideas we find ourselves living by. Values are to be found in experience, but their perception depends on the kind of stance we take toward experiencing itself. Our inability to register the importance of a situation, the meaning of a certain discourse or the truth of a certain world-view is due to our inability to take the right stance toward those situations, meanings and truths, one from which they appear desirable and alive for us or those who live them.

According to James, we are constantly on the verge of losing this grasp on reality for a variety of reasons: because of our depicting the pursuit of truth and meanings as an activity that doesn't require the involvement of our personal sensibilities, because of our inability to acknowledge that ideals, truths and values are the result of the particular description we make ourselves of reality, and because of the very nature of language which distorts the image we have of our inner life; in James' words, because of our tendency of 'taking the usual for granted.' However, once we have abandoned a picture of moral values and moral truths as the correspondence of our sensibilities to something brute or transcendental, in favor of a picture of them in terms of the inventive character of our experiencing - one which requires a personal inventive experimentation -, a very different picture of moral reflection, one long neglected in the recent history of philosophy, will be again regarded as respectable. It is in this sense that the moral psychology of human beings is directly relevant for the understanding of the character of moral reflection. The achievement of a description of reality that makes values hospitable in the world requires in the first instance a description of human experiencing as the very source of truth and values. This is a recurrent theme in James' philosophy, which he explores in depth in many occurrences of his intellectual biography, and it finds its most distinctive voice in MPML. After his 1891 address he never came back to the theme in these terms, perhaps due to the very poor reaction it generated, and tried instead to reaffirm its main tenets by following other paths. Although his later ethical writings were characterized by companion concerns, MPML remains the only theoretical treatment of this theme, and thus, as such, we ought to read it as a prolegomenon to the various moral inquiries it suggests we undertake. We should value the relative silence of the essay over the contents that should characterize moral discourse, since its point is precisely that of warning us against constricting ourselves in one or another narrow moral possibility, concentrating instead on the form moral reflection should take. This point, gone utterly unnoticed in the secondary literature, represents in my opinion the key to understanding both MPML and his later moral investigations. Despite its apparent abstractness, this indication has the most tremendous practical consequences, as the essays on moral blindness I briefly quoted testify. These are not the only possible ones, but the point of MPML is precisely that of indicating the path along which to proceed in doing moral philosophy, and not that of exhausting its possibilities. 
In this article I have argued that the notions of truth and invention represent the key to understanding the dialectic of MPML and its instructions about the point and shape of moral reflection. Once truth is seen as the peculiar engaged stance we can take toward experiencing, one whose character is inventive rather than passive, the internal tensions displayed in the discussion of the psychological, the metaphysical and the casuistic question cease to appear as such. In MPML James has struggled to present the complexities featuring the relationship between our moral life and moral thought, and the discussion of its underlying conception of truth has helped us in finding a key to understanding its dialectics. By resisting a certain picture of truth as ungrounded in our practices of experiencing we dismiss altogether certain difficulties haunting the characterization of our moral lives. If read as a piece of moral theory, MPML could appear rather unsatisfying, but if this paper has at least partially achieved its ambition of challenging the grounds of such a reading, then the project of shaping moral reflection along foundational lines will appear as less appealing. On closer inspection, James' essay conveys an interesting conception of moral reflection, whose greatest value consists in its capacity to shed light on the varieties of experiences surrounding our moral life. Its point, beyond doubt a Wittgenstenian one, rather than being that of telling what morality is, is that of showing how to grasp, understand and live with it.

\section{BIBLIOGRAPHY}

BERNSTEIN R. J., (1977), Introduction, in W. James, A Pluralistic Universe, Cambridge, Harvard University Press.

BERNSTEIN R. J., (1983), Beyond Objectivism and Relativism: Science, Hermeneutics and Praxis, Philadelphia, University of Pennsylvania Press.

BERNSTEIN R. J., (2010), The Ethical Consequences of William James's Pragmatic Pluralism, in The Pragmatic Turn, Polity Press, London.

BILGRAMI A., (2010), The Wider Significance of Naturalism. A Genealogical Essay, in Naturalism and Normativity, ed. by M. De Caro \& D. Macarthur, New York, Columbia University Press.

BIRD G., (1997), Moral Philosophy and the Development of Morality, in Putnam (1997b).

BJORK D. W., (1988), William James: The Center of His Vision, New York, Columbia University Press.

BORDOGNA F., (2008), William James at the Boundaries. Philosophy, Science, and the Geography of Knowledge, Chicago and London, The University of Chicago Press.

BRENNAN B., (1961), The Ethics of William James, New York, Vintage Books.

CAMPBell J., (1981), "William James and the Ethics of Fulfillment," Transactions of the Charles S.

Peirce Society, XVII, 3.

CARLSON T., (1997), James and the Kantian Tradition, in Putnam (1997b). 
CONANT J., (2001), Philosophy and Biography, in Wittgenstein. Philosophy and Biography, ed, by J. C. Klagge, Cambridge, Cambridge University Press.

DEWEY J., (1908), What Pragmatism means by 'Practical,' Journal of Philosophy, Psychology and Scientific Methods, 5, reprinted in The Collected Works of John Dewey 1882-1953, Middle Works, 4, Southern Illinois University Press.

DEWEY J., (1925), The Development of American Pragmatism, in ed. by the Department of Philosophy, Studies in the History of Ideas, New York, Columbia University Press, re-printed in The Collected Works of John Dewey 1882-1953, Later Works, 2, Southern Illinois University Press.

DIAMOND C., (1997), Moral Distances and Differences: Some Questions, in Communality and Particularity, ed. by L. Alanen, S. Heinämaa \& T. Wallgren, London, Macmillan- Houndsmill.

DONATELli P., (1998), Wittgenstein e l'etica, Roma-Bari, Laterza.

DONATElli P., (2005), “Alle origini del concetto di linguaggio morale," Etica \& Politica / Ethics \& Politics 1.

DRURY M., (1984), Some Notes on Conversations with Wittgenstein, in Recollection of Wittgenstein, ed. by R. Rhees, Oxford, Oxford University Press.

EDEL A., (1976), Notes on the Search for a Moral Philosophy in William James, in The Philosophy of William James, ed. by W. R. Corti, Hamburg, Felix Meiner Verlag.

FRANZESE S., (2008), The Ethics of Energy. William James's Moral Philosophy in Focus, Frankfurt, Ontos Verlag.

GALE R., (1999), The Divided Self of William James, Cambridge, Cambridge University Press.

Goodman R. B., (1990), American Philosophy and the Romantic Tradition, Cambridge, Cambridge University Press.

Goodman R. B., (2002), Wittgenstein and William James, Cambridge, Cambridge University Press.

Goodman R. B., (forthcoming), William James's Pluralisms.

GUNNARsSON L., (2010), The Philosopher as Pathogenic Agent, Patient, and Therapist: The Case of William James, in Philosophy as Therapeia, ed. by J. Ganeri \& C. Carlisle, Royal Institute of Philosophy Supplement, 66, Cambridge, Cambridge University Press.

JAMES W., (1890a), The Principles of Psychology vol. 1, New York, Henry Holt and Company, reprinted as The Principles of Psychology vol. 1, London, Dover, 1950.

JAMES W., (1890b), The Principles of Psychology vol. 2, New York, Henry Holt and Company, reprinted as The Principles of Psychology vol. 2, London, Dover, 1950.

JAMES W., (1897), The Will to Believe, and Other Essays in Popular Philosophy, New York, Longman, Green and Company, reprinted as The Will to Believe, Cambridge, Harvard University Press, 1979.

JAMES W., (1889a), On a Certain Blindness in Human Beings, in James (1889c).

JAMES W., (1889b), What Makes a Life Significant, in James (1889b).

JAMES W., (1889c), Talks to Teachers on Psychology and to Students on Some of Life's Ideals, New York, Henry Holt and Company, reprinted as Talks to Teachers on Psychology and to Students on Some of Life's Ideals, Cambridge, Harvard University Press 1983.

JAMES W., (1907), Pragmatism. A New Name for Some Old Ways of Thinking, New York, Longmans, Green and Company, reprinted as Pragmatism, Cambridge, Harvard University Press, 1975. 
JAMES W., (1909), The Meaning of Truth. A Sequel of Pragmatism, New York, Longmans, Green and Company, reprinted as The Meaning of Truth, Cambridge, Harvard University Press, 1975.

MARCHETTI S., (2011), “James, Nietzsche and Foucault on Ethics and the Self," Foucault Studies 11. MARGolis J., (1986) Pragmatism without Foundations. Reconciling Realism and Relativism, New York, Continuum (2nd ed.).

MCDOWELl J., (1979), “Virtue and Reason,” The Monist 62.

MYERS G., (1986), William James, His Life and Thought, London, Yale University Press.

O'SHEA J., (2000), Sources of Pluralism in William James, in Pluralism. The Philosophy and Politics of Diversity, ed. by M. Baghramian, London, Routledge.

PERRY R. B., (1935), The Thought and Character of William James vol. 2: Philosophy and Psychology, Boston, Little, Brown and Company.

PUTNAM H. \& R. PUTNAM, (1994), William James's Ideas, in Realism with a Human Face, ed. by J. Conant, Cambridge, Harvard University Press.

PUTNAM H., (1995), Pragmatism: An Open Question, Cambridge, Blackwell.

PUTNAm H., (2004), Philosophy as a Reconstructive Activity: William James on Moral Philosophy, in The Pragmatic Turn. Contemporary Engagements between Analytic and Continental Philosophy, ed. by W. Egginton \& M. Sandbothe, New York, SUNY Press.

PUTNAM R. A., (1985), “Creating Facts and Values,” Philosophy, 60 (232).

PUtnAm, (1987), “Weaving Seamless Webs,” Philosophy, 62 (240).

PUTNAm R. A., (1990), The Moral Life of a Pragmatist, in Identity, Character and Morality, ed. by A. O. Rorty, Boston, MIT Press.

PUTNAM R. A., (1997a), Some of Life's Ideals, in Putnam (1997b).

PUTNAm R. A. (ed.), (1997b), The Cambridge Companion to James, Cambridge, Cambridge University Press.

PUTNAM R. A., (1998), “Perceiving Facts and Values,” Philosophy 73 (283).

RORTY R., (1982), Consequences of Pragmatism, Minneapolis, University of Minnesota Press.

ROTH J. K., (1965), Freedom and The Moral Life. The Ethics of William James. Philadelphia, The Westminster Press.

SEIGFRIED C. H., (1990), William James's Radical Reconstruction of Philosophy, New York, State University of New York Press.

SLATER M. R., (2009), William James on Ethics and Faith, Cambridge, Cambridge University Press. SUCKIEL E. K., (1982), The Pragmatic Philosophy of William James, Notre Dame, University of Notre Dame Press.

TALISSE R. \& D. M. HESTER, (2004), On James, Toronto, Thomson Wadsworth. Williams B., (1985), Ethics and the Limits of Philosophy, Cambridge, Harvard University Press. WITTGENSTEIN L., (1959), Zettel, Oxford, Blackwell. WITTGENSTEIN L., (1958), Philosophical Investigations, Oxford, Blackwell (4th ed.). 


\section{NOTES}

1. Franzese (2008: 3). Although I wholeheartedly agree with the above claim by Franzese, our readings of MPML diverge in one important aspect: while for him the essay has only a negative aspiration - namely, that of showing how all foundational projects are doomed to fail - I think that it conveys a more positive message. Our disagreement amounts to the reading of the method of the essay. I will come back on this disagreement later in section 6 .

2. It is important to notice that James was very critical of the Benthamite version of utilitarianism, while much more sympathetic to John Stuart Mill's version, which was more attentive to the qualitative distinction between lower and higher pleasures. James' debt to Mill runs deep into his intellectual biography, and is acknowledged in the dedication of his most important work Pragmatism to him.

3. As an aside, whose full articulation would require much more investigation than I can pursue in the space of this essay, I would like to remark that the matter is even more complicated, given the presence of an interesting entanglement internal to James' own rhetoric about the nature of morality between the relationship of moral reflection with the moral life it should address and the relationship of MPML with the moral investigations pervading his other writings. That is, James' discourse in MPML about the nature of moral thought in respect to the moral life fosters the very same questionings about the place of this essay in the corpus of his writings. The very same intellectualistic understanding of the connection between moral reflection and the moral life affects also the understanding of the connection between MPML and the moral instructions suffused in his other works. James was deeply upset about the poor response to his lecture essay, and the reason for this lies in his readers' - and listeners' - misunderstanding of both these entanglements. He lamented such a misreading with the very same force with which he complained about the misunderstandings of his conception of truth as he portrays it in his Pragmatism and The Meaning of Truth. I suspect that, in his replies to these latter misunderstandings, James tried to give some instructions to remedy also the former misreading, and this is precisely because in order to appreciate the arguments advanced in MPML what is needed is a correct grasp of the picture of truth built into it. This shows, at least, how systematic and precise James' reflection was, and how misled are those detractors who portray his philosophy as lacking of rigor in his thinking. The difficulty of appreciating James' deep philosophical sensibility and precision is due to its contrast with the elusiveness of the material worked on. The sharp mind and arguments of James look watered down by the nature of their very objects of inquiry, which are by their nature as variegated, fuzzy and motley as the lives in which they are experienced. Therefore, James' chief, self-proclaimed goal, that is 'the reinstatement of the vague [and inarticulate] to its proper place in our mental life' (James 1890a: 254), requires a work that is as much accurate as sophisticated, one easy to miss due to the flamboyant character of the trail it must follow to chase its raw materials. This lesson holds both for his treatment of ethics, and for the understanding of his overall conception of philosophical activity. A resourceful reading of James' philosophical project that is attentive to these questionings is C. H. Seigfried (1990), in which the author engages in a thoughtful analysis of James' claims to systematicity, of their difficulties, shortcomings and misunderstandings.

4. A rough list of which numbers - in addition to the literature discussed or quoted along the essay - J. K. Roth 1965, M. R. Slater 2009, B. Brennan 1961, A. Edel 1976, E. K. Suckiel 1982, G. H. Bird 1997, and J. Campbell 1981.

5. Perry (1935: 250).

6. An analogous move is made by some recent accounts of James' philosophy. See, for example, L. Gunnarsson 2010, and D. W. Bjork 1988. Although very interesting both in their general point 
and for their insights into James' conception of philosophy as therapy, without doubt a major theme in James' intellectual biography, these readings tend to portray James' reflective discourse to a mere outcome of his personal strivings and idiosyncrasies. Even though I think that a detailed acquaintance with James' life represents a necessary element for the understanding of many of his ideas, I resist the reduction of the latter to the former. At least, some distinctions must be traced. In a nutshell, James' broader considerations about the nature of philosophy and the motives for philosophizing - the idea that one's temperament is a major factor in one's philosophical investigations - recalls an immediate connection between biography and philosophy, so that it is fair to say that when he speaks about them it is not only the philosopher James speaking, but the very man - and, moreover, he is not speaking only to philosophers, but to the flesh and blood human beings beneath them animating their thoughts. However, such anxieties are philosophical anxieties bearings on our lives and thus their discussion should proceed at a reflective level, even if their objects are the human beings with their questionings as they are expressed in their lives and practices. As regards James' (slightly) more limited considerations about the nature of morality, mindedness and worldliness the connection between biography and philosophy must be complicated, and although it is fair to say that some happenings in James' life prompted him to some reflections and shaped his way of seeing things, I resist this as merely the last thing to say about them. There is an activity of reflective underpinning that is beyond the discussion of morality or the nature of the mind, which is both instigated by, and bears on, our concrete lives and biographies, but whose dialectic and investigations are philosophical through and through. Russell B.Goodman puts this idea beautifully by saying that James' complaint that he was 'unfit to be a philosopher because at bottom he hates philosophy, especially at the beginning of a vacation, with the fragrance of the spruces and sweet ferns all soaking him through with the conviction that it is better to be than to define your being' is itself "of course [...] a philosophical statement" (Goodman 1990: 58). A similar concern is voiced by James Conant and Piergiorgio Donatelli about the understanding of the connection between biography and philosophy in Wittgenstein and in other great authors. See Conant 2001, and Donatelli (1998: 179-85). It was Wittgenstein himself who, speaking with Maurice Drury about good philosophical works, responded to Drury's comment that 'I always enjoy reading William James. He is such a human person,' by remarking 'Yes, that is what makes him a good philosopher; he was a real human being' (Drury 1984: 121).

7. Gale (1999: 26).

8. Gale (1999: 32). Gale mounts a very elegant and elaborate 'ladder argument,' running through nearly half his book, in which several variants of this principle are given as he brings into his initial 'practical syllogism' different elements of James' thought. I can't do justice to the complexity of his argument here, although I will indirectly go back to it later while presenting at more length my own reading of James' characterization of truth. I will save a detailed analysis and confrontation with Gale's powerful reading of James for another occasion, and I would like to thank prof. Gale for his very thoughtful advices and guidance during some very stimulating conversations on our disagreements.

9. For a discussion of this theme see Bernstein 1983, Rorty 1982, Putnam 1995, and Margolis 20072.

10. It is my interpretative claim that James has in mind the kind of normative descriptions Kant made of human beings in his Anthropologie in Pragmatischer Hinsicht. There are some historical evidences for this claim - collected by Perry in his masterwork on James' life and thought according to which James began reading Kant in his late twenties and early thirties, and the Anthropologie was the very first book of Kant he read. The first to remark James' (and Peirce's) debt to Kant was Dewey (1908a, 1925). Whereas Pierce's debt to Kant is much more widespread and documented, James' relationship with Kant is more difficult to ascertain and characterize, especially given James' harsh criticism of Kant in his published works. However, as many 
biographers have documented, Kant's Anthropologie was a book James admired, and which was very helpful in his early struggles for the elaboration of his own pragmatic conception of human beings. A very interesting examination of James' engagements with Kantian themes is given by T. Carlson 1997.

11. Borrowing the expression used by Alice Crary and Rupert Read to describe Wittgenstein's attitude toward the possibility of external elucidations of our human practices.

12. James (1897: 141).

13. Here James has in mind skepticism as it is has been conceived in the modern, Cartesian, tradition. However, there are some interesting connections also with Cavell's characterization of skepticism. These are addressed by Russell Goodman (1990: ch. 1 \& 3).

14. James (1897: 142).

15. Talisse \& Hester (2004: 57). The authors present this conception as a result of James' philosophical method of radical empiricism, whose connection with his pragmatism is the object of many investigations. Here I carry out my argument by using resources internal to James' pragmatism, making no reference to his radical empiricism, although a parallel point could be made by exploring James' conception of experience and experiencing as he pictures it in his writing on radical empiricism.

16. Talisse \& Hester (2004: 68).

17. This point has been raised in a slightly different way by Ruth Anna Putnam in her discussion of how to read James' insights about the role of character in our moral life. She writes "The title of William James' only systematic essay in moral philosophy - "The Moral Philosopher and the Moral Life" - suggests that a serious systematic thought about morality needs to focus on a whole life" (Putnam 1990: 68).

18. James (1899: 5).

19. The resoluteness is about the kind of reading James requires one to engage in while reading MPML. I use the term resolute as a reference to the reading that James Conant and Cora Diamond, among others, gave of Wittgenstein's Tractatus. A resolute reading is one which beware us how to read a certain text, and in particular how to read its statements in order to get the significance that the phrasing in which they are expressed tries to convey. For this reason, using the word resolute does not indicate a kind of interpretation of the text, but rather it points to a program of comprehension of the text: not what the author is saying, but rather what is he doing. While in Wittgenstein's Tractatus, as the authors cited have brilliantly showed us, this methodological instruction is explicit and self-standing, in James' MPML the instruction emerging from the dialectic of the essay can be fully apprehended only in the light of his general conception of philosophical problems that he fully explores in other text. It is thus my interpretative claim that in order to understand the kind of work James is doing in MPML one must look to his understanding of the nature of philosophical inquiries -and in particular to its characterization of the place of truth in morality.

20. James (1897: 204).

21. Cora Diamond wrote extensively on the dangerousness of what she calls 'a moralization of morality,' reading James as an author whose philosophy was driven by similar concerns. See in particular, Diamond 1997.

22. James (1897: 141).

23. This conception of the philosophical inquiry as the clarification of our activities and forms of life from the within has been explored at depth by Wittgenstein, who was a reader of James and praised him for stressing the importance of such an aspect. See Wittgenstein (1959: § 350) and Wittgenstein (20094: II $\S 366$ ). For a detailed analysis of Wittgenstein's debts to James, see Goodman 2002. The expression 'sideways on' is taken from John McDowell 1979, whose use of it is inspired by his resourceful reading of Wittgenstein (and Aristotle). 
24. For a critical assessment of the book by Franzese, see Marchetti 2011 where I spell out in more detail our disagreements as well as our like-mindedness on both this point and the wider reading of the whole of James' moral philosophy.

25. James (1897: 143).

26. James (1897: 143).

27. James (1897: 134).

28. The characterization of thick ethical concepts - and their difference from thin ones - is spelled out by Bernard Williams 1985. The distinction James is drawing here is close to the one Williams is interested in defending, and also its critical purposes are not unlike, although it is embedded in a very different conceptual apparatus.

29. James (1897: 134).

30. My terminological choices could be misleading, since by speaking of 'invention' - and contrasting it with 'discovery' - I could suggest the idea that here James is claiming that we 'create' values. However, I keep the world 'invention' because it is the one James uses in these passages, and here I'm trying to show how James uses it in reference to the stance we can take toward facts, one from which their values emerge. I would like to thank Akeel Bilgrami, who raised some perplexities on my use of 'invention' and gave me some useful suggestions to clarify my own thoughts on the matter. In my understanding of James' conception of moral values I have been inspired by Bilgrami's writings on enlightenment and enchantment, in which he portrays with great clarity and insight the contrast between an enchanted and a disenchanted conception of values. See, in particular, Bilgrami 2010.

31. For a survey of these themes, together with an interesting proposal of an alternative genealogy of their emergence, see Donatelli 2005.

32. James (1890a: 195).

33. Myers (1986: 70).

34. James (1897: 145).

35. This is what Russell B. Goodman, referring to Emerson and the American transcendentalist movement, has called a 'voluntaristic picture of knowledge,' according to which 'to know something [...] one must do something, taking a special attitude or stance' (Goodman 1990: 56). 'According to James a precondition for certain kinds of knowing or "communication with the nature of things" is an act or attitude of the knowing subject' (Goodman 2002: 70).

36. James (1897: 146).

37. James (1897: 147).

38. James (1897: 148).

39. James (1897: 148).

40. James (1897: 149-50).

41. James (1897: 152).

42. James (1897: 153).

43. James (1897: 154).

44. James (1897: 155).

45. James (1897: 155-6).

46. James, quite reasonably indeed, even relying on a very liberal conception of scientific inquiry, had a pre-Kuhnian conception of scientific discourse. However, I guess that, accordingly to some of his own innovative reflections on the character of psychological science and its developments in the nineteen century, he would have praised the guiding lines of Kuhn's insights about paradigm changes and the value ladenness of observations as pragmatic ideas. For a brilliant inquiry into James' conception of scientific discourse, see Bordogna 2008.

47. James (1897: 157-8).

48. James (1897: 158). The passage continues "[w]e should seek incessantly, with fear and trembling, so to vote and to act as to bring about the very largest total universe of good which we 
can see. Abstract rules indeed can help; but they help less in proportion as our intuitions are more piercing, and our vocations is the strongest for the moral life." This latter remark is surely tempted by utilitarian concerns about the inclusiveness of moral ideas, but again these normative concerns are re-interpreted by James along non-foundational lines, as exhortations rather than as principles.

49. MPML has a last section in which James quarrels about the difference that the existence of god would make for his discourse on the nature of ethics. He asks whether, given his characterization of the relationship between moral reflection and the moral life, the postulation of some divine spectator would make some difference in our way of portraying it. I tend to downplay the importance of this section in the architecture of essay, not because it is uninteresting, but rather because there James tackles a question that, despite its pertinence, is external to James' main line of argumentation and does not add anything to the main argument of the essay. In fact, there James discusses some important issues that are more in the line of continuity with his other well-known essay The Will to Believe, which are but an integration of the discourse of MPML. The two essays share many point of contact in some crucial aspects, but I think that, for their proper understanding, it is better to keep them separated and read them as two arrows pointing in the same direction rather than as two strings of the very same argumentation sharing many of their materials. I cannot pursue the analogy further here.

50. Rivers of ink has been spilled over James' notion of truth. At the risk of appearing ingenuous, here I will not discuss any of the relevant literature - since that would go beyond the scope of the present essay -, and will proceed straight to a very personal survey of Pragmatism and The Meaning of Truth in order to sort out those central insights of James' position that are congenial to the larger point I am making in the present essay. Still, I think that the 'ethical path' through which I articulate James' notion of truth represents a major strand in his overall conception.

51. James (1907: 37).

52. James (1907: 42).

53. James (1907: 42).

54. James (1907: 104).

55. James (1907: 97).

56. James (1907: 97).

57. James (1907: 119).

58. James (1909: 5).

59. James (1909: 43).

60. For example, in metaphysical terms, as the opposition between Monism vs. Pluralism. For a discussion on these lines, one relevant for the ethical discourse, see Bernstein 1977, 2010; Goodman (forthcoming); and O'Shea 2000.

61. James (1899a: 132).

62. James (1899a: 133).

63. James (1899a: 149).

64. James (1897: 159).

65. James (1899b: 150).

66. James (1899b: 163).

67. Putnam (1997a: 293).

68. Putnam (1994: 217).

69. Putnam (1994: 223). Hilary Putnam has reinstated this point in Putnam 2004. Ruth Anna Putnam has elaborated this insight in Putnam 1985, 1987, and 1998.

70. James (1890b: 565-6).

71. James (1897: 148). 


\section{ABSTRACTS}

In what follows I shall investigate how the notions of truth and invention inform our moral life. William James explored at depth this theme in his seminal essay The Moral Philosopher and the Moral Life (MPML). I will claim that the dialectics of the essay cannot be apprehended independently from the understanding of the moral psychology and epistemology James elaborates in his writings on pragmatism and the philosophy of mind. In fact, once framed in the relevant perspective, the essay conveys a very different and more radical position that the one usually acknowledged. In MPML James engages in an inquiry into the nature of moral thought and its ability to meet the difficulties of the moral life it should address. The essay criticizes a certain image of moral reflection by questioning its underlying assumptions about the nature of mindedness and the place of truth in the moral life. I shall thus articulate the discussion of James' essay along two directions, one methodological and one substantive. They are, respectively, the anti-foundational and anti-theoretical character of moral reflection, and the rethinking of the relationship we have with our interiority that is relevant for ethics as informed by the notion of truth.

\section{AUTHOR}

\section{SARIN MARCHETTI}

Sapienza Università di Roma, Italy

sarin.marchetti[at]gmail.com 